
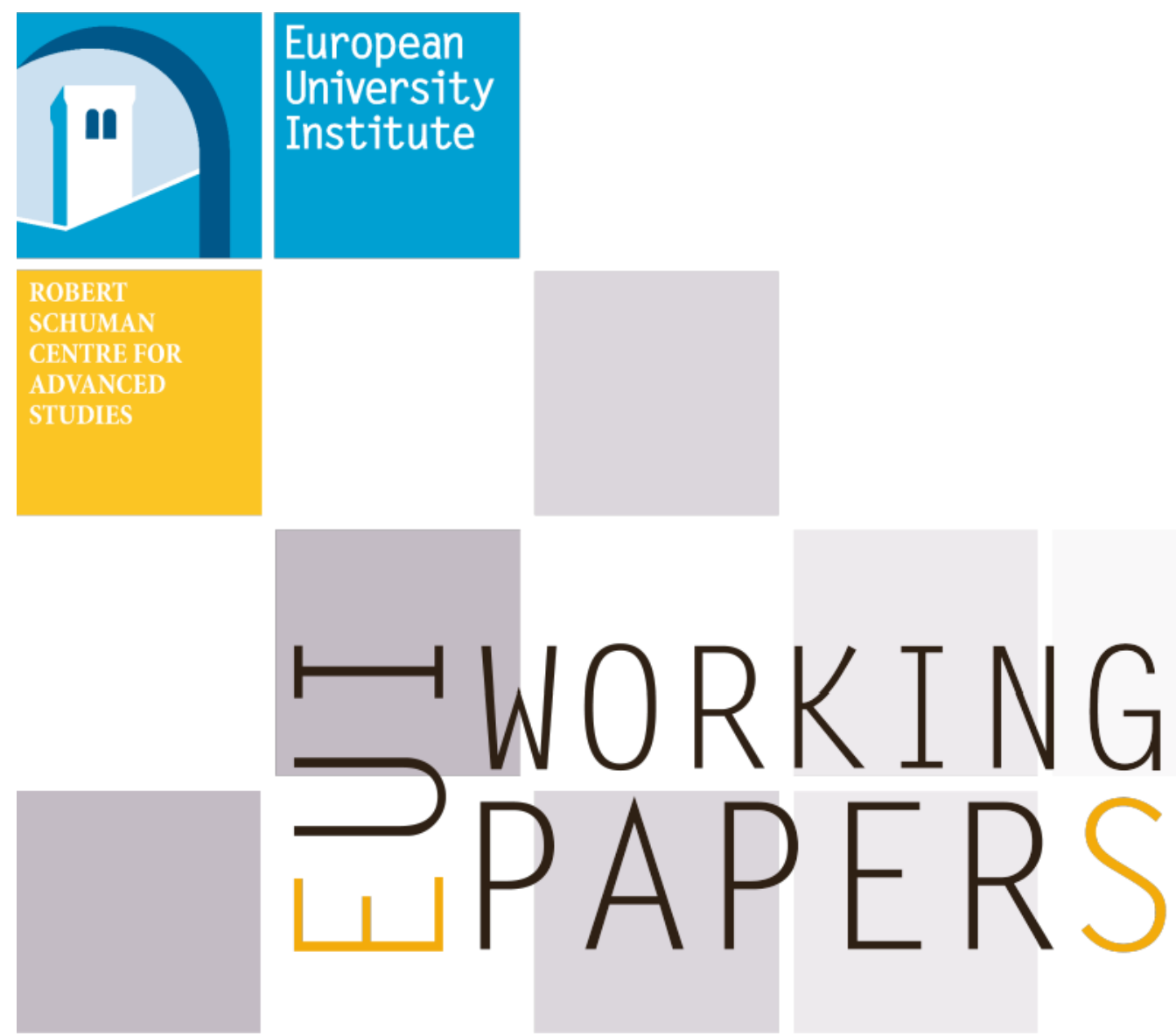

RSCAS 2017/21

Robert Schuman Centre for Advanced Studies Global Governance Programme-263

Trade Shocks and Far-Right Voting:

Evidence from French Presidential Elections

Clément Malgouyres 

European University Institute

Robert Schuman Centre for Advanced Studies

Global Governance Programme

Trade Shocks and Far-Right Voting:

Evidence from French Presidential Elections

Clément Malgouyres

EUI Working Paper RSCAS 2017/21 
This text may be downloaded only for personal research purposes. Additional reproduction for other purposes, whether in hard copies or electronically, requires the consent of the author(s), editor(s). If cited or quoted, reference should be made to the full name of the author(s), editor(s), the title, the working paper, or other series, the year and the publisher.

ISSN 1028-3625

(C) Clément Malgouyres, 2017

Printed in Italy, March 2017

European University Institute

Badia Fiesolana

I - 50014 San Domenico di Fiesole (FI)

Italy

www.eui.eu/RSCAS/Publications/

www.eui.eu

cadmus.eui.eu 


\section{Robert Schuman Centre for Advanced Studies}

The Robert Schuman Centre for Advanced Studies (RSCAS), created in 1992 and directed by Professor Brigid Laffan, aims to develop inter-disciplinary and comparative research and to promote work on the major issues facing the process of integration and European society.

The Centre is home to a large post-doctoral programme and hosts major research programmes and projects, and a range of working groups and ad hoc initiatives. The research agenda is organised around a set of core themes and is continuously evolving, reflecting the changing agenda of European integration and the expanding membership of the European Union.

Details of the research of the Centre can be found on:

http://www.eui.eu/RSCAS/Research/

Research publications take the form of Working Papers, Policy Papers, Policy Briefs, Distinguished Lectures, Research Project Reports and Books.

Most of these are also available on the RSCAS website:

http://www.eui.eu/RSCAS/Publications/

The EUI and the RSCAS are not responsible for the opinion expressed by the author(s).

\section{The Global Governance Programme at the EUI}

The Global Governance Programme is one of the flagship programmes of the Robert Schuman Centre for Advanced Studies at the European University Institute (EUI). It aims to: build a community of outstanding professors and scholars, produce high quality research and, engage with the world of practice through policy dialogue. At the Global Governance Programme, established and early career scholars research, write on and discuss, within and beyond academia, issues of global governance, focussing on four broad and interdisciplinary areas: European, Transnational and Global Governance; Global Economics; Europe in the World; and Cultural Pluralism.

The Programme also aims to contribute to the fostering of present and future generations of policy and decision makers through its unique executive training programme, the Academy of Global Governance, where theory and "real world" experience meet. At the Academy, executives, policy makers, diplomats, officials, private sector professionals and academics, have the opportunity to meet, share views and debate with leading academics, top-level officials, heads of international organisations and senior executives, on topical issues relating to governance.

For more information: http://globalgovernanceprogramme.eui.eu 



\title{
Trade Shocks and Far-Right Voting: Evidence from French Presidential Elections
}

\author{
Clément Malgouyres* \\ Banque de France \\ First version: December 2013 \\ This version: March, 2017
}

\begin{abstract}
The rise of radical right parties is a Europe-wide phenomenon. While many studies describe the individual or regional characteristics associated with high propensity to vote for the far-right, we know little about the causal impact of economic shocks on electoral support for the far-right. Over the period 1995-2012, we examine the impact of trade-shocks, measured as exposure to low-wage country import competition, on the local vote share of the National Front, the French main far-right party, during presidential elections. We use small communities (cantons) as units of observations and include province (département) fixed effects, so that the identifying variation comes from within-province change in imports exposure over time. We find evidence of a small but significantly positive impact of import competition exposure on votes for the far-right: a one standard-deviation increase in imports-per-worker causes the change in the far-right share to increase by 7 percent of a standard deviation. Further results suggest that this effect has been increasing over the time period considered. We conduct a simple sensitivity test supporting the notion that (i) omitting local share of immigrants is likely to bias our estimate downward, and that (ii) this bias is likely to negligible.
\end{abstract}

\section{Subdisciplinary classification: Political Economy}

Key Words: Far-Right, Voting Behavior, Local Labor Markets, Trade, import competition

*email address: clement.malgouyres@banque-france.fr. The views expressed here are those of the authors only and do not necessarily reflect the views of the Banque de France or the Eurosystem. This work is supported by a public grant overseen by the French National Research Agency (ANR) as part of the "Investissements d'avenir" program (reference : ANR-10-EQPX-17 Centre daccs scuris aux donnes CASD). 



\section{Introduction}

Extreme right populist parties (ERPP) have received large electoral support in many West European countries since the 1980s (Ignazi, 2003). ${ }^{1}$ These repeated successes, continued over the 2000s and arguably magnified by the crisis, contrast with the experience of radical left which has gone through a relative decline across Europe since 1989 (March and Mudde, 2005). Given the weight of the far-right in the political debate and the radical measures it proposes to implement, understanding the causal factors behind its electoral success appears an important endeavor. ${ }^{2}$

Hostility to immigration is one of the traditional defining features of ERPP (Kitschelt, 1995). Immigration has accordingly been the focus of a large share of the empirical research on the farright. While many papers have documented a correlation between hostility to foreigners and support for the far-right, ${ }^{3}$ Halla et al. (2013) provide the first causal estimate of immigration on the electoral success of ERPPs, for the case of Austria. Controlling for local economic conditions and instrumenting for current level of immigrants' presence at the neighborhood level with historical settlement patterns, they find a substantial positive impact of immigration on the electoral share for the FPO (the Austrian ERPP).

Immigration however is only one dimension of ERPPs' programs. Over the 1990s, ERPPs across Europe have been increasingly vocal detractors of globalization (Zaslove, 2008). That trend has pursued over the 2000s. Academic research has increasingly investigated and supported the notion that the far-right's appeal grew among those who considered themselves as losing out from rising economic integration (Kitschelt, 2007). The transformation of the electoral basis as well as of the economic agenda of the far-right is perhaps most evident in France. The National Front (FN henceforth) has increasingly focused on economic precariousness, pointing at globalization as the main culprit behind the difficulties faced by the workers while proposing increasingly "leftist" policies (Ivaldi, 2013). Meanwhile it has been the main recipient of "working-class" votes during the presidential elections of 2002, 2007 and 2012. ${ }^{4}$ While a large

\footnotetext{
${ }^{1}$ Ignazi (2003) p.200 documents that for Austria, Italy, France, Belgium, Norway, and Switzerland such parties have scored about $10 \%$ of votes in national parliamentary elections during the 1990s.

${ }^{2}$ Regarding the influence of the far-right, Bale et al. (2010) document and attempt to explain the how social democratic parties adapt to the rise of far-right populist parties in Northern European countries. Williams (2006) studies and provides evidence regarding the role of far-right as a agenda-setter in France, Germany, and Austria.

${ }^{3}$ There are two main strands in this literature. The first uses cross-country regressions relating immigration share to electoral success of the far-right. The second uses survey data where respondents document their opinion their opinion about immigration and their political preferences.

${ }^{4}$ Working-class employees ("ouvriers" in French) made up about 25 percent of the working-age population as of 2005 (INSEE, 2013).
} 
literature has described the progressive "proletarization" of ERPPs over the 1990s and 2000s, and analyzed the social and economic correlates of electoral support for the far-right, ${ }^{5}$ there is still little knowledge about the causal effect of local economic conditions on its electoral success. This paper aims at filling this gap by treating more carefully the issue of endogeneity of economic shocks with respect to voting outcomes as well as improving the measurement of such shocks.

In this paper, we estimate the impact of trade-induced economic shocks on the local electoral success of the far-right in France. ${ }^{6}$ An obstacle to studying empirically the impact of international competition on voting outcomes lies in the difficulty to obtain a measure of import competition with enough variation without resorting to cross-country regressions from which it is hard to draw causal conclusions. ${ }^{7}$ We construct a panel of small geographical units ("canton-ville" of which there are about 3,500 in mainland France and which we will refer to as communities) for France. We circumvent the issue of measurement by interacting the initial sectoral composition of each community with nationwide sector-specific imports originating from low-wage countries, thus obtaining within-country cross-sectional variation in import competition exposure (This approach was pioneered by Autor et al. (2013)). We use a model in first-difference with departement-period fixed-effects (there are 96 departements in mainland France), and accordingly rely on within-departement cross-sectional variation in changes in import competition between each election to estimate the effect of interest.

We find evidence of a positive and significant modest effect of import competition. On average, an increase in change in imports-per-worker (denoted as $\Delta I P W$ ) of $\$ 1000$ causes a rise in 0.4 percentage point in change in the far-right share of votes between two elections. Due to rising variation in exposure to import competition over time, this constant coefficient translates into an increasing normalized effect overtime. For the period 1995-2002, 2002-2007 and 2007-2012, increasing of one period-specific standard deviation in imports-exposure causes support for the far-right to rise by, respectively, $2.7 \%, 6.6 \%$ and $8.98 \%$ of a standard deviation. Allowing the estimated coefficient to vary over time, we find mixed evidence of an increasing effect overtime. We assess the robustness of our results with respect the local share of immigrants, a well-documented factor of support for the far-right, and conclude that omitting a local

\footnotetext{
${ }^{5}$ For instance, Jackman and Volpert (1996)'s study finds cross-country evidence that ERPP benefit from high unemployment. This seminal paper has started a large literature on the topic.

${ }^{6}$ This paper thus reverses the focus of Halla et al. (2013) in the sense that it concentrates on local economic shocks while accounting for the local presence of foreigners. Halla et al. (2013) proceed the other way around and are not particularly interested in the effect of economic shocks.

${ }^{7}$ For instance, Levine and Zervos (1993) provide, in the context of "growth empirics", an exposition of the general statistical and conceptual issues associated with cross-country empirical studies.
} 
measure of migrant presence introduce little bias in our estimate. France, as many countries of Western Europe, has experienced the increasing electoral success of the far-right since the early 1980s. The far-right was absent of the 1981 French presidential election. It first made an impressive breakthrough in 1984 during the EU elections when it received 11 percent of votes. ${ }^{8}$ Ever since, it scored above 14 percent in all but 2007 presidential elections with an average score around 15 percent. $^{9}$ The last election 2012 saw the highest score ever achieved by the Front National, at 17.9 percent, 1 percentage point above the score realized by Jean-Marie Le Pen in 2002 (when he qualified for the second round). The period we cover (1995 to 2012) is particularly interesting as it has been marked by a programmatic shift in the economic discourse of the FN. Ivaldi (2013) shows that it has recently moved away from free-market oriented programs towards redistributive, protectionist and social policies. Moreover, economic issues have gained more prominence in the party's discourse. French presidential elections lend themselves well to the study of the impact of local economic conditions on voting behavior as voters across the entire country choose from same set of candidates. This is unlike legislative elections where parties appoint a different candidate in each electoral district, which could lead to confound the effect of trade shocks with that of parties' candidate choice of an optimal candidate for a given district.

The focus on low-wage import competition is justified by its tremendous growth over the past two decades. Chinese exports in particular have been growing in constant value at an astounding pace of 15 percent per year. The potential labor market effects of such steep progression has given rise to a heated political debate in most high-income economies. This rapidly rising economic openness has occurred concomitantly to the "proletarianization" of the European far-right parties (both in terms of electoral support and programmatic focus). By documenting some of the political consequences of globalization, we contribute to inform the debate on the cost and benefits of increasing economic integration with low-cost countries.

Our paper is related to a large empirical literature on the contextual factors of support for the far-right. As pointed out by Arzheimer (2009): "Research on the voters of the extreme right in Western Europe has become a minor industry...". However, although there exist many studies relating some measure of economic hardship to far-right voting, there are very few studies

\footnotetext{
${ }^{8}$ The noted electoral success of the new far-right was during a local by-election in 1983 , where the FN and other mainstream right-wing parties formed a coalition to defeat the socialist candidate during the second round (Gaspard, 1990).

${ }^{9}$ During the 2007 election, Nicolas Sarkozy managed to divert a large share of FN voters (Mayer, 2007). He did so by stressing issues usually dear to the core FN electorate, notably national identity and immigration control. However, there is a suspicion that this shift towards the right of the mainstream right parties facilitated, in the medium-run, the so-called de-demonisation of the FN (Mayer, 2013a).
} 
looking at the impact of international competition on the electoral support for ERPPs that deal explicitly with the issue of endogeneity. This is surprising given the impressive increase in imports penetration by low-wage countries (most notably China) over past two decades and the large consequences this process has had on the labor market markets in high-income countries, particularly on the labor market outcomes of low-skill workers, the subset of the population which is the most inclined to support the far-right. ${ }^{10}$ Two recent exceptions are Dippel et al. (2017) and Colantone and Stanig (2017). Colantone and Stanig (2017) use data on European regions in order to analyze the impact of rising trade competition from China onto the rise of economic nationalism. We follow a very similar empirical approach but focus on within-region variation in import competition to achieve identification, thus allowing to compare communities affected differently by low wage country competition but yet located very close to one another. The paper most similar to ours is Dippel et al. (2017). It investigates the impact of import competition and export opportunities on radical right voting in Germany. Their results suggest that import competition increased the share of the right radical votes and that this effect is mostly mediated by labor market turmoil. The French context is interesting as it is characterized by larger labor market impact of import competition and larger support for the far-right - whereas the German far-right gather much smaller votes on average. However, we do not attempt to unpack the estimated coefficient into different mechanisms but focus instead on estimating the overall reduced-form effect in a context where it is likely to be of greater significance.

Another paper that falls close to ours in terms of substantive question (rather than method) is Swank and Betz (2003). The authors assess the effect of trade-openness on the electoral success of ERPPs and investigate how this effect varies with welfare state institutions (that are likely to mitigate the redistributive impact of trade liberalization). They use cross-country variation in trade-openness (measured as trade-to-GDP ratio), ERPP voting shares and welfare-state institutions within Western Europe during the 1980s and 1990s. They find no direct effect of trade-openness and a negative interaction effect between high degree of social protection and trade-openness, supporting the notion that increase in public spending allows to compensate

\footnotetext{
${ }^{10}$ There is a large literature regarding the labor market effect of low-wage country competition. Most relevant to us is the work by Autor et al. (2013) which shows that locations intensive in Chinese-import competing industries in the USA tend to have lower employment rate. This effect outside of manufacturing affects primarily low-skill workers. For Europe, Bloom et al. (2011) show that firms facing strong Chinese competition tend innovate more but cut employment, especially among production jobs. This study backs the notion that a share of the observed skill-biased technical change is in fact induced by trade with low-wage countries and finds no evidence of such phenomenon associated with other high-income countries. Mion and Zhu (2013) use data on Belgian manufacturing firms and show that Chinese imports are particularly disruptive, due perhaps to their high degree of sophistication conditional on Chinese wage rates (Rodrik, 2006) and cause firm to reduce employment, upgrade the average skill of their workforce and increase their share of non-production workers. Malgouyres (2014) finds large local effect of import competition from China on employment, labor earnings and the structure of occupations (polarizing impact within manufacturing).
} 
losers from trade liberalization (Rodrik, 1998). It is difficult to draw causal statements about the effects of trade shocks from cross-country data as countries differ in many other dimensions and policies. Hence, while Swank and Betz (2003) include many control variables, it remains unclear that no not-controlled-for mechanisms drives differences in aggregate ERPP electoral share. While working-class/production worker status predicts strongly support for the FN, Oesch (2008) shows that electors of the Front National, for the year 2002, cared mostly about social issues (cultural homogeneity) rather than economic issues. This result is confirmed by Mayer (2013b) for the 2012 election. Naturally, given the issues associated with survey data regarding the self-identification as far-right voters, it seems plausible that only the most radicalized part of the electorate self-identifies themselves as far-right voters thus resulting in a selected sample. ${ }^{11}$ Our findings suggest that the documented correlation between working-class status and support for the FN does not purely reflect the heterogeneity of preference for cultural homogeneity across socio-economic categories, but that instead economic shocks have been, by themselves, causing a rise in the support for the far-right.

This paper is also related to the literature on the impact globalization on voting outcomes. Most of this literature is framed within either the Heckscher-Ohlin or Ricardo-Viner models and aims at testing their predictions in terms of attitude towards trade-openness using survey data. Scheve and Slaughter (2001) look at whether individuals' skills and/or industry of employment matter for trade-policy preferences and finds support for the HO model in that factor-type is a more decisive determinant of trade-policy preferences than industry of employment. They also find that, independently of factor-type or industry of employment, homeowners in areas whose industries are intensively exposed to international competition are more likely to hold protectionist view. This last finding is interesting in that it suggests that beyond people directly employed in imports-competing industries, communities are susceptible to vote for anti-globalization parties through the home-owning channel, industrial decline leading ultimately to lower land prices. Mayda and Rodrik (2005) roughly confirms the predictions of a standard HO model for skilled individuals but not for low-skill ones. However, measurement error is a serious issue in both of these studies as industry of employment has to be inferred from individuals'occupation and education. This limits the reliability of their test of the specific-factor model. Interestingly for our purpose, they find that even after controlling for socio-economic situation, individuals more hostile to trade-openness tend also to hold nationalistic/chauvinistc opinion. This finding

\footnotetext{
${ }^{11}$ For instance, as shown in Oesch (2008), 11.4 percents only of the respondents to the 2002/2003 wave of the European Social Survey acknowledged to have voted for the Front National while the FN gathered 16.9 percents of valid votes during the first round of the presidential election of May 2002.
} 
is corroborated by Mansfield and Mutz (2009). This could imply that following a trade-shock, impacted voters deciding to vote for a protectionist party are likely to support far-right party.

More closely related to our paper is Margalit (2011) which analyzes electoral outcomes at the local level. The author uses an innovative measure of trade-induced layoffs in the United-States that he constructed by collecting the number of assistance requests under the Trade Adjustment Act for each county from 1996 to 2004. He then looks at the impact of such requests on the share of votes for the incumbent in the 2004 Presidential elections. The author finds that trade-induced job destruction has a negative effect on the incumbent share. Moreover, he finds that this effect exists above and beyond local economic conditions as it is still present after controlling for local unemployment. We depart from this paper by looking at the electoral effect of a general measure of trade-exposure (as opposed to focusing on layoffs). Moreover, we focus on electoral support for the Front National, a party with a clear anti-immigration and anti-globalization platform, as opposed to looking at incumbent effect. More over, while our measurement of exposure to import competition captures not only possibly job losses but also a host of other effects - lower real wage growth, stress at work (Colantone et al., 2015) - that might be driving radical voting.

Finally, Autor et al. (2016) estimate the impact of Chinese import competition on "political polarization", that is electing politicians at the very left or very right of the political spectrum in congressional elections. I use the same empirical approach in a different context, the first round of French presidential elections. The first round of French presidential elections is interesting in that a single candidate is running in front of the whole electorate. This limits the scope for parties to tailor their offer to the particular economic conditions of a given district - for instance by sending candidates with more or less anti-globalization stances or blue-collar background in trade impacted areas. The setting allows us to partial out political party-driven "supply side" factors and focus instead on the demand side of the electoral market - holding the political offer constant across different districts.

The rest of the paper is organized as follow. Section 2 presents some background on the farright in France and introduce the data and measurement of imports-exposure. Section 3 presents the specification and some descriptive evidence. Section 4 shows the results and discusses them. The conclusion follows. 


\section{Data and measurement}

We intend to measure the impact of exposure to import competition from low-wage countries on the propensity of communities to vote for the far-right. Hence the paper resorts to data on vote, trade and local sectoral composition of employment. The data on votes come from the Interior Ministry and are at the municipality level (there are about 36,000 municipalities in France). The DADS (Déclaration annuelle de données sociales) dataset is an exhaustive matched employer-employee administrative dataset containing information for all employees of the nonfarm private sector in France. We use it to measure the sectoral structure of local employment. Publicly available data on bilateral trade flows are used to measure imports (UN Comtrade). More details on the mapping of products (Comtrade) into sectors (DADS) is provided in the appendix A.

Formally, we start by computing a index of imports exposure, called "Imports-per-Worker" according the following formula:

$$
\Delta I P W_{i t}=\sum_{s} \frac{L_{i s t}}{L_{i t}} \frac{\Delta M_{s t}}{L_{s t}}
$$

where $M_{s t}$ stands for imports from low-wage countries to France for sector/period st, $L_{s t}$ is equal to employment in France for sector/period st, $L_{i t}$ is total employment in area/period it, and $\Delta x_{t}$ refers to changes in variable $x$ between periods $t$ and $t+1$. We use the list of manufacturing intensive low-wage countries as established by Auer et al. (2013). The list includes six-countries: China, India, Malaysia, Mexico, the Philippines and Thailand. ${ }^{12}$

We improve measurement by explicitly accounting for interdependence between cantons by using the shares of workers initially commuting from one canton to another. That is, for each canton $i$ we compute a weighted average of all cantons imports exposure $\left(\Delta I P W_{j t}\right.$ for $j=1, \ldots, N$ when $N$ is the number of cantons) using commuting shares between canton $i$ and $j$ during the initial year as weights. Formally, the index to be used in the estimation is defined as the following:

$$
\Delta \overline{I P W}_{i t}=\sum_{j} \eta_{i j t} \Delta I P W_{j t}
$$

, where $\eta_{i j t}$ is the share of workers living in canton $i$ and working in canton $j$ at time $t$ (beginning of the period).

\footnotetext{
${ }^{12}$ Auer et al. (2013) is a extension to Europe of the work on the deflationist impact of low-wage country imports for the United-states by Auer and Fischer (2010).
} 


\subsection{Descriptive statistics and geographical overview}

Table 1 presents some community-level statistics. The median electoral size of a "canton" is 7,000 registered voters. The change in FN voting share between the first rounds of 1995 and 2012 is 3.18 percentage point on average with substantial variation across areas (standard deviation on 4.70 percent). The simple and commuting-adjusted measures of imports exposure have roughly the same mean, the simple measure has a much larger standard deviation than commuting-adjusted measure. It stems from the fact that it is computed as a convex combination of the simple measure. In economic terms, it conveys the notion that employment opportunities do not vary as dramatically across space as the local presence of jobs, because of the possibility of workers to commute to different communities to take up jobs.

Figure 1 shows the spatial distribution of FN votes. The blue lines corresponds to province (or département) boundaries. The left panel (a) show the vote in 1995. The strongest concentrations of FN votes in the South-East and along the Mediterranean coast, around Lyon, in the East (Alsace and Moselle) and North and East of Paris. A regression of FN shares on a full set of province dummies yield an R-square of 70 percent, suggesting there is not much within-province variation. The right panel (b) displays the change in local shares of FN votes between 1995 and 2012. The average increase is 3.8 points but there is a lot of variation around the mean. The most impressive gains were realized in the very North and in the center and West of France. Gains in the East (Alsace) were limited but 1995-level was very high as most communities there had FN shares comprised between 20 and 30 percent in 1995. The R-square of a regression of change in FN voting share on a full set of province dummies is equal to 50 percent implying that within-province variation is higher in changes than in levels.

Figure 2 displays the spatial distribution of the imports-exposure index. Panel (a) shows the simple index while (b) shows the commuting-adjusted index. A comparison of the Southern most province along the Western side between Panel (a) and (b) illustrates the difference between the two measure. While Panel (a) shows only a couple of very exposed communities (colored in dark red) surrounded by unexposed ones (colored in light pink or white), adjusting for commuting patterns in Panel (b) diffuses the exposure and smoothes it, with many communities facing intermediate level of exposure (colored in darker shades of pink). 
The crux of our empirical approach is to relate the within-province (entities delimited by the blue lines) variation from Panel (b) Figure 1 to within-province variation from Panel (b) Figure 2.

\section{Empirical approach}

\subsection{Baseline specification}

We adopt the following specification:

$$
\Delta F N_{i t}=\beta \Delta \overline{I P W}_{i t}+X_{i t}^{\prime} \delta+\gamma_{d(i), t}+\varepsilon_{i t}
$$

, where $i t$ refers to canton $i$ during period $t$ to $t+1 . \Delta F N_{i t}$ is the change in voting share of the FN. $\triangle \overline{I P W}_{i t}$ has been defined above. $X_{i t}$ is a set of demographic controls from the Census. It includes: total population, a set of share of total population for sex $s$ and age category $a$ with 7 different age categories (0-14 year old, 15-29 year old, ..., 90 year old and more). The data come from the Census of 1990 (associated with the 1995-2002 period), 1999 (associated with the 2002-2007 period), 2006 (associated with the 2007-2012 period). $\varepsilon_{i t}$ is an idiosyncratic shock that we assume uncorrelated with the regressors. The term $\gamma_{d(i), t}$ represents a province-period fixed effect.

Adopting a first-difference model allow us to control for time-invariant heterogeneity. Given the inclusion of period $\times$ province (or département in French) dummies, the identifying variation under this specification comes from within-province cross-sectional variation in changes in exposure to low-wage country imports. Yet, there is a suspicion that domestic nation-wide sectoral shocks might driving imports from low-wage countries. To the extent that these shocks might also be affecting or correlated to support in the far-right, they will bias the OLS estimates of Equation 3. In the next subsection, we present the instrumental variable approach we follow to deal with this issue. 


\subsection{Instrumental variable approach to deal with the endogeneity of sectoral imports}

Nation-wide sector specific shocks (supply or demand) are partly driving the amount of goods imported in France from abroad. If these shocks affect simultaneously sectoral imports and votes for the far-right, through their impact on labor market outcomes for instance, OLS estimates will be biased. As sectoral shocks are likely to affect each community differently depending on local characteristics, period fixed-effects do not absorb such shocks. In this section, we formalize this argument to motivate and explain our instrumental variable approach. ${ }^{13}$

Consider the following data generating process (for simplicity, we ignore covariates, the crosscommuting shares weighing and omit the time subscript):

$$
\Delta F N_{i}=\alpha_{0} \Delta I P W_{i}+e_{i}
$$

We recall the definition of $\triangle I P W_{i}$.

$$
\Delta I P W_{i}=\sum_{i} \frac{L_{i s}}{L_{i}} \frac{\Delta M_{s}}{L_{s}}=\sum_{s} \theta_{i s} \frac{\Delta M_{s}}{L_{s}}=\sum_{s} \theta_{i s} m_{s}
$$

The share of employment in sector $s$ in location $i$ is denoted $\theta_{i s}$ and $m_{s}$ is the change in imports to initial employment ratio for sector $s$. For simplicity, we consider it as a parameter (i.e. non stochastic) here.

We consider the case where the error terms $e_{i t}$ is composed of (i) a weighted sum of nation-wide sectoral supply and demand shocks (which we denote $w_{s}$ and $x_{s}$ respectively) and (ii) a proper error term uncorrelated with any other terms included in the regression.

$$
e_{i t}=a_{S} \sum_{s} \lambda_{i s} w_{s}+a_{D} \sum_{s} \lambda_{i s} x_{s}+\varepsilon_{i}
$$

where the parameter $a_{S}$ and $a_{D}$ determines the sign and magnitude of the impact of supply and demand shocks, respectively, on the changes in the voting share of the FN and $\lambda_{i s}$ is an unobserved term representing the "importance" of sector $s$ in location $i$ (hence it is expected to be highly similar to $\theta_{i s}$ ). We can rewrite equation (4) as:

$$
\Delta F N_{i}=\alpha_{0} \theta_{i}^{\prime} \mathbf{m}+\lambda_{i}^{\prime}\left(a_{S} \mathbf{w}+a_{D} \mathbf{x}\right)+\varepsilon_{i}
$$

where $\mathbf{w}$ and $\mathbf{x}$ are vectors respectively containing the nation-wide sector-specific supply and

\footnotetext{
${ }^{13}$ This approach was pioneered by Autor et al. (2013).
} 
demand shocks, and $\mathbf{m}$ is the vector containing the changes in imports to initial employment ratios. This specification is reminiscent of panel model with interactive fixed-effect (Bai, 2009) in the sense that the unobserved heterogeneity term $\lambda_{i}$ is multidimensional (the length of vector $\lambda_{i}$ is here equal to the number of sectors in the economy) and is allowed to interact with shocks that are common through the rest of the cross-sectional units.

Hence OLS estimation of the main specification will be biased due the covariance between $\Delta I P W_{i}$ and $\lambda_{i}^{\prime}\left(a_{S} \gamma+a_{D} \psi\right)$ which we can write as:

$$
\operatorname{cov}\left(\theta_{i}^{\prime} \mathbf{m}, \lambda_{i}^{\prime}\left(a_{S} \mathbf{w}+a_{D} \mathbf{x}\right)\right)=a_{S} \theta_{i}^{\prime} \operatorname{cov}(\mathbf{m}, \mathbf{w}) \lambda_{i}+a_{D} \theta_{i}^{\prime} \operatorname{cov}(\mathbf{m}, \mathbf{x}) \lambda_{i}
$$

We assume that $s \neq s^{\prime} \Rightarrow \operatorname{cov}\left(m_{s}, w_{s^{\prime}}\right)=\operatorname{cov}\left(x_{s}, w_{s^{\prime}}\right)=0$ which amounts to ignoring crosssectors relationships (driven for instance by input-output linkages or substitution in consumption between goods). Therefore we get the following expression:

$$
\operatorname{cov}\left(\theta_{i}^{\prime} \mathbf{m}, \lambda_{i}^{\prime}\left(a_{S} \mathbf{w}+a_{D} \mathbf{x}\right)\right)=a_{S} \sum_{s} \theta_{i s} \lambda_{i s} \operatorname{cov}\left(m_{s}, w_{s}\right)+a_{D} \sum_{s} \theta_{i s} \lambda_{i s} \operatorname{cov}\left(m_{s}, x_{s}\right)
$$

We expect the covariance between nationwide unobserved sectoral supply shocks and importsper-worker $\left(\operatorname{cov}\left(m_{s}, w_{s}\right)\right)$ to be negative. When French producers in sector $s$ are subject to a negative supply shock $\left(w_{s}<0\right.$ e.g. mandatory nation-wide reduction in weekly working-time with no reduction in monthly wages), one would expect an increase in purchase in goods $s$ from foreign suppliers, including China and other low-wage countries. That $\operatorname{suggests} \operatorname{cov}\left(m_{s}, w_{s}\right)<0$. On the other hand, as $x_{s}$ represents demand shocks, one would expect that $\operatorname{cov}\left(m_{s}, x_{s}\right)>0$.

Economic hardship is supposed to increase the support for the far-right, hence we have $a_{S}<0$ and $a_{D}<0$. According to this framework, the bias introduced by unobserved sectoral shocks could either be positive or negative depending on the relative magnitude of supply and demand shocks and how they affect imports from low-wage country. Because these nation-wide shocks affect each community differently, through to the vector $\lambda_{i}$, including periods fixed-effects does not solve the issue.

We resort to an instrumental variable strategy whereby we instrument actual exports from low-wage countries to France by Chinese exports to a set of high-income countries whose eco- 
nomic cycle is weakly related to that France. ${ }^{14}$ The formula for the instrument is the following:

$$
\Delta I P W_{i t}^{o}=\sum_{s} \frac{L_{i s t}}{L_{i t}} \frac{\Delta M_{s t}^{o}}{L_{s t}}
$$

where $\Delta M_{s t}^{o}$ is Chinese exports to the set of selected other high-income countries. The identifying assumption underpinning the validity of this instrument is that Chinese exports to these countries are independent from domestic shocks in France and that the correlation between French imports from low-wage countries and Chinese exports to these countries is only driven by supply-side improvements in China or common to China and other low-wage countries.

\subsection{Discussion of the treatment effect captured by $\overline{I P W}$}

A variable that is closely related to $\overline{I P W}_{i t}$ is the Bartik-instrument (Bartik, 1991). It interacts initial sectoral shares with nation-wide sectoral trends in employment growth. The Bartikvariable is typically used an instrument for local unemployment or shift in local labor demand. For our purpose, i.e. estimating the impact of trade shocks on the voting share of the far-right, we do not think $\overline{I P W}_{i t}$ can be used as an instrument for a specific labor market outcome, such as local unemployment rate. Indeed, there are many potential channels other than unemployment through which imports exposure can negatively affect labor market outcomes (downward pressure on wages, increase in working flexibility and rates etc.), thus suggesting that the exclusion restriction is not satisfied. Hence, our estimates should be interpreted as the reduced-form impact of increase in low-wage import competition. Isolating the causal channels will the object of further research. As illustrated by Margalit (2011), it could be that trade shocks have an electoral impact above and beyond their effect on the labor market. Previous work in France suggest that local labor demand shocks likely to push youth unemployment up are associated with rise in crime (Fougre et al., 2009) which could be another channel. One appeal of using the index $\overline{I P W}$ index in a specification relying on local variation is that it captures a diffuse and comprehensive effect unlike a spectacular plant-closure which would be likely, notably through media-exposure, to contaminate nearby or even distant locations.

\footnotetext{
${ }^{14}$ These countries are the same as in Dauth et al. (2014) and include: Australia, Canada, Japan, New Zealand, Norway, Singapore, Sweden, United Kingdom. We excluded all countries from continental Europe which are part of the euro zone.
} 


\section{Results}

\subsection{Baseline results}

We present the baseline results from OLS estimation in Table 2. Column (1) display the coefficient for a specification with no other covariates. The introduction of demographic structure roughly halves the estimated coefficients (Column (2)). The introduction of controls for education diminishes further the estimated relationship as can be seen in Column (3) with a point estimate of 0.27 . All three estimates are significantly different than 0 at the 1 percent confidence level.

It is no entirely clear at first whether education should be included in our regression. Indeed, it is likely that the share of college workers is affected by trade shocks. There is an important literature documenting the mobility differential in response to local labor market shocks which concludes, roughly, that college educated workers are much more likely to move out of declining labor market than lower educated workers (Notowidigdo, 2011). ${ }^{15}$ As result, communities struck by large increase in imports exposure are likely to see their share of college educated workers decrease, relatively to other communities. To deal with this issue, I use the share in the adult population which completed a college degree for the Census year 1990, that is before imports from low-wage countries represented a significant share of French external trade.

As discussed above, nation-wide sector imports might reflect not only the rise of competitiveness of low-wage countries but also domestic demand and supply shocks. In order to isolate the supply-driven change in exposure to low-wage country imports, we instrument $\Delta \overline{I P W}_{i t}$ with $\triangle \overline{I P W}_{i t}^{o}$. The results are displayed in Table 3. We see Column (2) that the IV estimate with no covariate exceed its OLS counter-part by about third with a point estimate of 0.945 . The point estimate is twice lower when demographic controls are included and is not affected much by the inclusion of the 1990 college share. Column (3) estimate of 0.41 implies that on average over the period 1995-2012, an increase in $\overline{I P W}_{i t}$ by one cross-sectional standard deviation raise the change in electoral support for the far-right by about 7 percent of a standard deviation.

\footnotetext{
${ }^{15}$ Most of this literature is based on US data. We are not aware of studies documenting this fact for France.
} 


\subsection{Local presence of immigrants}

\subsubsection{Instrumenting for the current presence of migrants}

Much of the literature on the contextual factors driving votes for the far-right is concerned with the effect of immigration. In our empirical setting and given data availability, it would be possible to control for the local share of employees that are foreigners and/or born abroad. However, as argued convincingly by Halla et al. (2013), the local presence of foreigners is most likely endogenous with-respect-to the voting share of the far-right. There are many channels, notably the local supply of public housing in the case of France, through which a community that is particularly prejudiced against immigrants and hence very likely to massively vote for the FN, could manipulate the presence of immigrants. Moreover, immigrants might be reluctant to settle in areas where they face a high level of discrimination.

To deal with this issue, Halla et al. (2013) uses historical settlement patterns of foreigners as an instrument for current immigration. This approach is ubiquitous in the literature on the labor market effect of migration (e.g. Altonji and Card (1991)). The assumption is that while past settlements are highly correlated with current immigration, because migrants of a given nationality tend to locate in the host country where co-nationals are already established, they are unrelated to the current outcome of interest. While the application of this instrument to the study of the labor market is rather uncontroversial as there is little suspicion that past immigration affect current wage through any other channel than the current level of immigration, there are reasons to doubt that the exclusion restriction underpinning the validity of the instrument is plausible when the dependent variable is a voting outcome. Historical settlement patterns, even if they are initially exogenous, are likely to affect the opinion of natives with respect to migrants over the entire period between the initial settlement and the period at which the election is held, through the presence of migrants over the entire intermediary period. Hostility to migrants might arise at some point in time years ahead of the studied election, which might in turn affect the propensity of migrants to locate in this community.

Taking stock of the difficulty of directly dealing with the endogeneity of the share of foreigners in the context of electoral studies, rather than including it in our regressions, we use it to bound the effect of interest for different assumptions regarding the magnitude of the true effect of immigration on vote for the far-right. 


\subsubsection{Assessing the bias for different assumptions on the effect of immigration}

Consider our main specification:

$$
\Delta F N_{i t}=\beta_{1} \Delta I P W_{i t}+\beta_{2} \Delta I_{i t}+X_{i t}^{\prime} \delta+\gamma_{d(i), t}+\varepsilon_{i t}
$$

We can rewrite the equation in terms of residuals as:

$$
\widetilde{\Delta F N}_{i t}=\beta_{1} \widetilde{\Delta I P W}_{i t}+\beta_{2} \widetilde{\Delta I}_{i t}+\epsilon_{i t}
$$

where $\widetilde{x}_{i t}$ refers to the residual from the regression of $x_{i t}$ on the set of exogenous regressors (i.e. $X_{i t}^{\prime}$ and $\gamma_{d(i), t}$ ). Estimating Equation (7) using $\widetilde{\triangle I P W}_{i t}^{o}$ as an instrument and omitting $\widetilde{\Delta I} i$ from the regression yield an estimator for $\beta_{1}$ which converges in probability towards:

$$
\operatorname{plim}\left(b_{1}^{I V}\right)=\frac{\operatorname{cov}\left(\widetilde{\Delta F N}, \widehat{\Delta I P W}^{o}\right)}{\operatorname{cov}\left(\widetilde{\Delta I P W}, \widetilde{\Delta I P W}^{\circ}\right)}=\beta_{1}+\beta_{2} \frac{\operatorname{cov}\left(\widetilde{\Delta I}, \widetilde{\Delta I P W}^{o}\right)}{\operatorname{cov}\left(\widetilde{\triangle I P W}, \widetilde{\Delta I P W}^{o}\right)}
$$

Notice that here we use the maintained assumption that $\operatorname{cov}\left(\epsilon, \widetilde{\triangle I P W}^{\circ}\right)=0$, i.e. our instrumental approach to deal with the endogeneity of imports to nation-wide sectoral imports is valid. Given our sample estimates for $(\mathbf{i}) \operatorname{cov}\left(\widetilde{\Delta I}, \widehat{\triangle I P W}^{\circ}\right)$ and (ii) $\operatorname{cov}\left(\widetilde{\triangle I P W}, \widehat{\triangle I P W}^{\circ}\right)$, we can compute the bias for different values of the unknown causal coefficient $\beta_{2}$. We report results for the specification of Column (3) from Table 3 in Table 4. The results clearly show that given that the ratio $\frac{\operatorname{cov}\left(\widetilde{\triangle I}, \widetilde{\triangle I P W}^{\circ}\right)}{\operatorname{cov}\left(\widetilde{\triangle I P W}, \widehat{\triangle I P W}^{\circ}\right)}$, even assuming strong positive effect of immigration on far-right votes, the implied bias is very low. Our estimates therefore appear quite robust to the exclusion of the immigration variable. In the next subsection, we provide evidence that our estimate is robust to whether communities included where subject to high or low immigrants presence in 1982.

\subsubsection{Heterogeneity across communities: past level of immigration}

In this paragraph, we present results where the sample has been split according to whether a community was above or below the median presence of immigrants in 1982 (a time at which the FN was still a rather obscure political party). Table 5 . We see the effect is roughly similar for both half of the sample (Columns (2) and (3)). If anything, the effect appears to be stronger in the bottom half, a pattern confirmed by results for the bottom and top terciles of the distribution, displayed in columns (4) and (5). Note however that the difference between the estimates is not statistically different. 


\subsection{Further results}

We assess whether this impact has changed overtime, allowing the treatment to be periodspecific. Results are displayed in Table 6. It shows that for all specifications, only the last period is driving the results. This is consistent with the notion that the economic crisis triggered in 2008 and recent FN's programmatic shift have contributed to increase the marginal impact economic shock on far-right voting. Estimates in columns (2), (3) suggest a normalized effect of 14.8 and 13.7 percent of a standard deviation respectively (Notice that the normalized impact goes up in comparison with results from Table 3 both because of the change in estimate and because the ratio $\sigma(\Delta \overline{I P W}) / \sigma(\Delta F N)$ is higher in the last period than on average).

I also carried additional tests of mechanisms at play in set of unreported regressions whose results are available upon request. First I investigate the role of voter turnout. A rise in the farright's electoral share (defined as the ratio of votes for the FN over the number of expressed valid votes) following a trade shock could stem from a decline in voter turnout that is heterogenous across political tendencies. The number of votes for the far-right could be stable but its electoral share still rise if the trade shock triggers a decline in turnout among citizens less prone to vote for the far-right. However, I do not find any statistical evidence of an impact on voter turnout of import competition on voter turn-out. Another channel driving the effect could be that the composition of registered voters is altered by the trade shocks. For instance, it could be that following a shock to the local labor market, people less prone to vote for the far-right might leave declining areas while potential voters for the far-right are less mobile. This is plausible in light of the documented tendency of highly educated people to be more responsive to local shocks than lower-educated people (Notowidigdo, 2011) and of the negative association between education and propensity to vote for the far-right (see e.g. Mayer, 2007). However I do not find any significant effect of trade shocks on local level of population (unfortunately I cannot measure migrations directly) or the local share of college graduates. These two results imply that the estimated positive effect is not driven by either a differential decline in voter turnout nor a change in the composition of local population of registered voters. They suggest therefore that the effect is likely to reflect an increase in the absolute number of votes received by the far-right locally and that this local positive effect was not offset by an "export" of non far-right voters to less trade exposed communities. Import competition seems therefore likely to have raised not only the relative support for the far-right across communities but its overall support at the national level. 


\section{Discussion and conclusion}

In this paper, we study the impact of imports-exposure of local communities in France on their propensity to vote for the far-right. Investigating this issue is important to gauge the relevance of economic factors in the vote for the far-right. As the National Front is promoting policies that, for some of them, question the founding values of liberal democracy, while some others, can be considered, more mundanely, poor economics (protectionism, tax cuts and spending increases, uncoordinated exit of the euro area etc.), it is highly relevant in terms of public policy and social welfare to assess whether local trade-shocks foster its electoral success. Our focus on low-wage import competition is justified by the rapid growth of such competition over the past 20 years and the stronger impact on the labor market it has been shown to have.

The results assembled in this paper suggest a small but significant effect of imports exposure on the propensity of communities to vote for the FN. Over the last four presidential elections in France, a one standard deviation increase in imports-exposure has been associated on average with a 7 percent increase in the change in the far-right voting share. We have shown evidence suggesting that not controlling for local degree of immigration is unlikely to cause substantial bias in our findings. The effect of industrial decline on vote have changed over time, benefitting the far-right mainly during the last period (2007-2012) which can be interpreted as the combined effect of the Great Recession and the focus of the National Front on economic hardship issues. 


\section{References}

Altonji, J. G. and CARD, D. (1991). The Effects of Immigration on the Labor Market Outcomes of Less-skilled Natives. In Immigration, Trade and the Labor Market, NBER Chapters, National Bureau of Economic Research, Inc, pp. 201-234.

Arzheimer, K. (2009). Contextual factors and the extreme right vote in western europe, 19802002. American Journal of Political Science, 53 (2), pp. 259-275.

Auer, R. and Fischer, A. M. (2010). The effect of low-wage import competition on u.s. inflationary pressure. Journal of Monetary Economics, 57 (4), 491 - 503.

Auer, R. A., Degen, K. and Fischer, A. M. (2013). Low-wage import competition, inflationary pressure, and industry dynamics in Europe. European Economic Review, 59 (C), $141-166$.

Autor, D., Dorn, D., Hanson, G. and Majlesi, K. (2016). Importing Political Polarization? The Electoral Consequences of Rising Trade Exposure. Working Paper 22637, National Bureau of Economic Research.

Autor, D. H., Dorn, D. and Hanson, G. H. (2013). The china syndrome: Local labor market effects of import competition in the united states. American Economic Review, 103 (6), $2121-68$.

BAI, J. (2009). Panel data models with interactive fixed effects. Econometrica, 77 (4), 1229 1279 .

Bale, T., Green-Pedersen, C., Krouwel, A., Luther, K. R. and Sitter, N. (2010). If you can't beat them, join them? explaining social democratic responses to the challenge from the populist radical right in western europe. Political Studies, 58 (3), 410-426.

Bartik, T. J. (1991). Who Benefits from State and Local Economic Development Policies? No. wbsle in Books from Upjohn Press, W.E. Upjohn Institute for Employment Research.

Bloom, N., Draca, M. and Reenen, J. V. (2011). Trade Induced Technical Change? The Impact of Chinese Imports on Innovation, IT and Productivity. NBER Working Papers 16717, National Bureau of Economic Research, Inc.

Colantone, I., Crin, R. and Ogliari, L. (2015). The Hidden Cost of Globalization: Import Competition and Mental Distress. Tech. rep. 
— and Stanig, P. (2017). The Trade Origins of Economic Nationalism: Import Competition and Voting Behavior in Western Europe. Working Paper 2017-49, BAFFI CAREFIN Centre Research Paper.

Dauth, W., Findeisen, S. and Suedekum, J. (2014). The rise of the east and the far east: German labor markets and trade integration. Journal of the European Economic Association, pp. n/a-n/a.

Dippel, C., Gold, R., Heblich, S. and Pinto, R. (2017). Instrumental Variables and Causal Mechanisms: Unpacking The Effect of Trade on Workers and Voters. Working Paper 23209, National Bureau of Economic Research.

Fougre, D., Kramarz, F. and Pouget, J. (2009). Youth unemployment and crime in france. Journal of the European Economic Association, 7 (5), 909-938.

Gaspard, F. (1990). Lvolution du fn dreux et dans ses environs. Revue Politique et Parlementaire, pp. 62-69.

Halla, M., Wagner, A. F. and Zweimller, J. (2013). Immigration and Voting for the Extreme Right. University of Zrich Department of Economics Working Paper Series 83, University of Zrich.

Ignazi, P. (2003). Extreme Right Parties in Western Europe. Oxford u.a.: Oxford University Press.

INSEE (2013). France, portrait social. Insee Rfrences, (1312).

IVALDI, G. (2013). A new radical right economic agenda? The transformation of the Front National in France. Workshop on "radical right-wing populists and the economy", University of Groningen.

JaCKMAN, R. W. and VolPert, K. (1996). Conditions favouring parties of the extreme right in western europe. British Journal of Political Science, 26, 501-521.

Kitschelt, H. (1995). The Radical Right in Western Europe. A Comparative Analysis. Ann Arbor: The University of Michigan Press.

- (2007). Growth and persistence of the radical right in postindustrial democracies: Advances and challenges in comparative research. West European Politics, 30 (5), 1176-1206. 
Levine, R. and Zervos, S. J. (1993). What We Have Learned about Policy and Growth from Cross-Country Regressions? American Economic Review, 83 (2), 426-30.

Malgouyres, C. (2014). Chinese imports competitions impact on employment and the wage distribution: evidence from French local labor markets. Tech. rep.

Mansfield, E. D. and Mutz, D. C. (2009). Support for free trade: Self-interest, sociotropic politics, and out-group anxiety. International Organization, 63, 425-457.

March, L. and Mudde, C. (2005). What's left of the radical left? the european radical left after 1989: Decline and mutation. Comparative European Politics, pp. 1472-4790.

Margalit, Y. (2011). Costly jobs: Trade-related layoffs, government compensation, and voting in u.s. elections. American Political Science Review, 105, 166-188.

Mayda, A. M. and Rodrik, D. (2005). Why are some people (and countries) more protectionist than others? European Economic Review, 49 (6), 1393-1430.

Mayer, N. (2007). Comment nicolas sarkozy a rétréci l'électorat le pen. Revue franaise de Science Politique, 57 (3-4), 429-445.

- (2013a). The de-demonisation of the Front National. Tech. rep., Policy Network/Barrow Cadbury Trust, project on Populism, Extremism and the Mainstream.

— (2013b). From jean-marie to marine le pen: Electoral change on the far right. Parliamentary Affairs, 66 (1), 160-178.

Mion, G. and ZhU, L. (2013). Import competition from and offshoring to China: A curse or blessing for firms? Journal of International Economics, 89 (1), 202-215.

Notowidigdo, M. J. (2011). The Incidence of Local Labor Demand Shocks. NBER Working Papers 17167, National Bureau of Economic Research, Inc.

OEsch, D. (2008). Explaining workers' support for right-wing populist parties in western europe: Evidence from austria, belgium, france, norway, and switzerland. International Political Science Review, 29 (3), 349-373.

RoDRIK, D. (1998). Why do more open economies have bigger governments? Journal of Political Economy, 106 (5), pp. 997-1032.

- (2006). What's So Special about China's Exports? Working Paper 11947, National Bureau of Economic Research. 
Figure 1: Spatial distribution of FN votes in 1995 and changes between 1995 and 2012

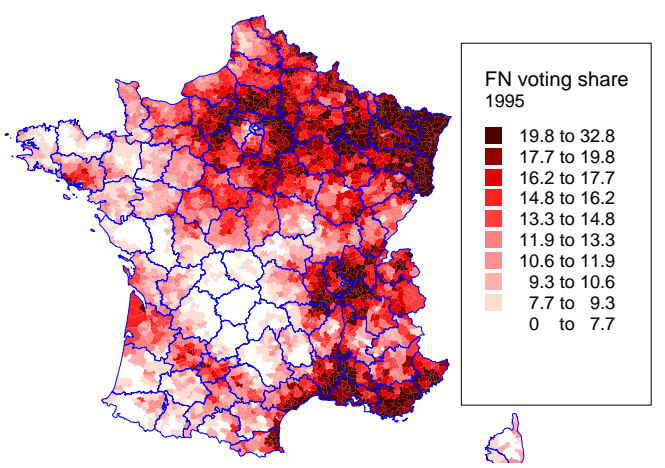

(a) 1995

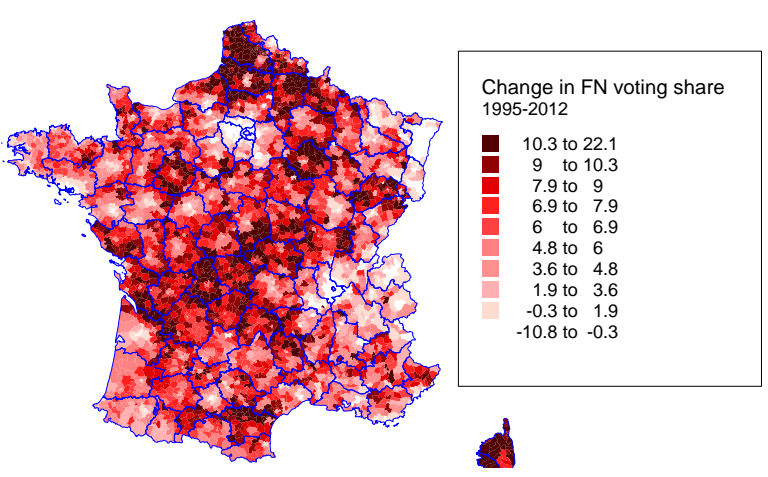

(b) 1995-2012

Scheve, K. F. and Slaughter, M. J. (2001). What determines individual trade-policy preferences? Journal of International Economics, 54 (2), 267 - 292.

Swank, D. and Betz, H.-G. (2003). Globalization, the welfare state and right-wing populism in western europe. Socio-Economic Review, 1 (2), 215-245.

Williams, M. H. (2006). The Impact of Radical Right-Wing Parties in West European Democracies. Ann Arbor: Palgrave Macmillan.

Zaslove, A. (2008). Exclusion, community, and a populist political economy: The radical right as an anti-globalization movement. Comparative European Politics, (2), 169189.

\section{Tables and figures}

Table 1: Descriptive statistics

\begin{tabular}{lccccc}
\hline Variables & Mean & Sd & p10 & p50 & p90 \\
\hline Registered voters & 10,527 & 14,495 & 2,482 & 7,160 & 20,562 \\
$F N$ & 14.21 & 4.38 & 8.53 & 14.00 & 20.06 \\
$\Delta F N$ & 0.87 & 6.07 & -7.82 & 1.40 & 8.69 \\
$\Delta I P W$ & 0.6823 & 1.058 & 0.053 & 0.34 & 1.62 \\
$\Delta \overline{I P W}$ & 0.675 & 0.540 & 0.140 & 0.570 & 1.40 \\
Share Foreigners & 10.79 & 7.21 & 2.29 & 9.08 & 21.52 \\
$\Delta$ Share Foreigners & -0.00 & 6.70 & -7.77 & -0.00 & 9.46 \\
\hline
\end{tabular}


Figure 2: Spatial distribution of $\triangle I P W$ and $\Delta \overline{I P W} 1995$ to 2012

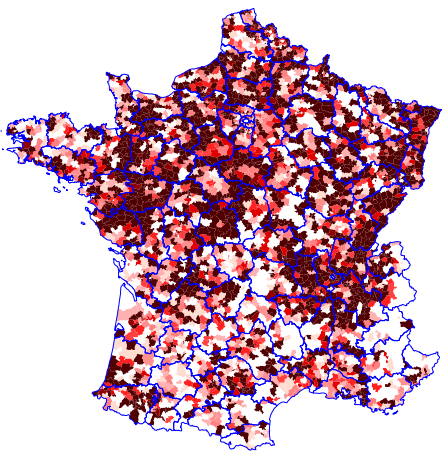

(a) $\triangle I P W$

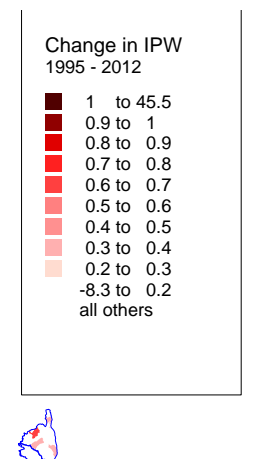

(1)

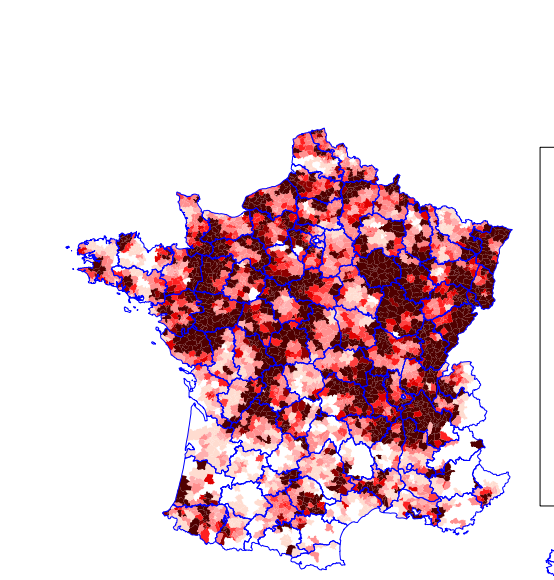

(b) $\triangle \overline{I P W}$

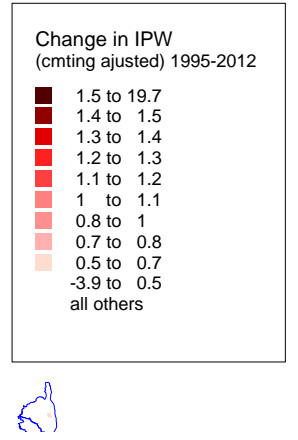

(cmting ajusted) 1995-2012

(1.

Table 2: OLS: First-Difference with Departement-Year FE, $\triangle \overline{I P W}$

\begin{tabular}{|c|c|c|c|c|c|}
\hline \multirow{2}{*}{$\overline{\Delta \overline{I P W}}$} & $\begin{array}{c}(1) \\
\text { OLS }\end{array}$ & $\begin{array}{c}(2) \\
\text { OLS }\end{array}$ & \multicolumn{2}{|c|}{$\begin{array}{c}(3) \\
\text { OLS }\end{array}$} & $\begin{array}{l}(4) \\
\text { OLS }\end{array}$ \\
\hline & $\begin{array}{c}0.660^{* * *} \\
(0.0743)\end{array}$ & $\begin{array}{c}0.335^{* * *} \\
(0.0529)\end{array}$ & \multicolumn{2}{|c|}{$\begin{array}{c}0.324^{* * *} \\
(0.0537)\end{array}$} & $\begin{array}{c}0.341^{* * *} \\
(0.0537)\end{array}$ \\
\hline $\begin{array}{l}\text { Region-Year FE } \\
\text { Demographic structure } \\
\text { College share } 1990 \\
\text { Working Class Share } 1990^{b}\end{array}$ & $\sqrt{ } \sqrt{ }$ & $\begin{array}{l}\sqrt{ } \\
\sqrt{ }\end{array}$ & $\begin{array}{l}\sqrt{ } \\
\sqrt{ } \\
\sqrt{ }\end{array}$ & 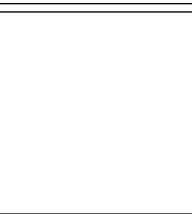 & $\begin{array}{l} \\
V \\
V \\
V \\
V\end{array}$ \\
\hline$N$ & 10140 & 10140 & 101 & & 140 \\
\hline \multicolumn{6}{|c|}{$\begin{array}{l}\text { Notes: The sample consists of } 3380 \text { cantons, observed over } 3 \text { periods: } 1995-2002-2007-2012 . \text { Robust clustered standard errors ar } \\
\text { reported between brackets. Corsica is excluded from the sample. } \triangle I P W \text { is expressed in thousands of dollar. }{ }^{a} \text { : Demographi } \\
\text { controls include the age-sex distribution for } 7 \text { different categories }(0-15 \text { year old, } 16-24, \ldots, 74-90,90 \text { and more), population and } \\
\text { population-squared. } b \text { : Share of population with a higher education degree and share of population whose occupation is manua } \\
\text { worker ("ouvrier") as } 1990 \text {. Regressions are weighted by } 1990 \text { Census population. }{ }^{*} \mathrm{p}<.10 * * \mathrm{p}<.05,{ }^{* * *} \mathrm{p}<.01 \text {. }\end{array}$} \\
\hline \multicolumn{6}{|c|}{ Table 3: IV: First-Difference with Departement-Year FE, $\Delta \overline{I P W}$} \\
\hline & (1) & (2) & (3) & $(4)$ & (5) \\
\hline & OLS & IV & IV & IV & IV \\
\hline & $\mathrm{b} / \mathrm{se}$ & $\mathrm{b} / \mathrm{se}$ & $\mathrm{b} / \mathrm{se}$ & $\mathrm{b} / \mathrm{se}$ & $\mathrm{b} / \mathrm{se}$ \\
\hline$\overline{\triangle \triangle \overline{I P W}}$ & $\begin{array}{l}0.660^{* * *} \\
(0.074)\end{array}$ & $\begin{array}{l}0.945^{* * *} \\
(0.113)\end{array}$ & $\begin{array}{l}0.401^{* * *} \\
(0.082)\end{array}$ & $\begin{array}{l}0.351^{* * *} \\
(0.082)\end{array}$ & $\begin{array}{l}0.340^{* * *} \\
(0.082)\end{array}$ \\
\hline $\begin{array}{l}\text { Region-Year FE } \\
\text { Demographic structure } \\
\text { College Share } 1990 \\
\text { Working Class Share } 1990^{b}\end{array}$ & $\sqrt{ }$ & $\sqrt{ }$ & $\begin{array}{l}\sqrt{ } \\
\sqrt{ }\end{array}$ & $\begin{array}{l}\sqrt{ } \\
\sqrt{ } \\
\sqrt{ }\end{array}$ & $\begin{array}{l}\sqrt{ } \\
\sqrt{ } \\
\sqrt{ } \\
\sqrt{ }\end{array}$ \\
\hline Cragg-Donald Stat & & 7594.5 & 7097.4 & 7015.4 & 6588.1 \\
\hline KP stat & & 365.4 & 343.8 & 343.1 & 324 \\
\hline$N$ & 10140 & 10140 & 10140 & 10140 & 10140 \\
\hline
\end{tabular}

Notes: The sample consists of 3380 cantons, observed over 3 periods: 1995-2002-2007-2012. Robust clustered standard errors are reported between brackets. Corsica is excluded from the sample. $\triangle I P W$ is expressed in thousands of dollar. ${ }^{a}$ : Demographic controls include the age-sex distribution for 7 different categories (0-15 year old, 16-24, . , 74-90, 90 and more), population and population-squared. Regression are weighted by 1990 Census population. ${ }^{*} \mathrm{p}<.10 * * \mathrm{p}<.05,{ }^{* * *} \mathrm{p}<.01$ 
Table 4: Estimated bias of $b_{1}^{I V}$ for different assumptions regarding the causal effect of immigration

\begin{tabular}{lcccccc}
\hline Value for $\beta_{2}$ & -5 & -3 & 0 & 3 & 5 & 10 \\
\hline $\begin{array}{l}\text { Table 3 Col } 3 \\
\left(b_{1}^{I V}=0.41, r=-0.002621\right)\end{array}$ & 0.0131 & 0.0078 & 0 & -0.0078 & -0.0131 & -0.0262 \\
Table 3 Col 4 & 0.0131 & 0.0079 & 0 & -0.0079 & -0.0131 & -0.0263 \\
$\left(b_{1}^{I V}=0.35, r=-0.00263\right)$ & & & & & & \\
Table 3 Col 5 & 0.0120 & 0.00723 & 0 & -0.007235 & -0.0120 & -0.0241 \\
$\left(b_{1}^{I V}=0.34, r=-0.002241\right)$ & & & & & & \\
\hline
\end{tabular}

Notes:

The table display the value of $\beta_{2} \operatorname{cov}\left(\widetilde{\Delta I}, \widetilde{\Delta I P W}^{\circ}\right) / \operatorname{cov}\left(\widetilde{\Delta I P W}, \widetilde{\Delta I P W}^{\circ}\right)$ given empirical estimates $\operatorname{cov}\left(\widetilde{\Delta I}, \widetilde{\Delta I P W}^{\circ}\right)$ and $\operatorname{cov}\left(\widetilde{\triangle I P W}, \widetilde{\triangle I P W}^{\circ}\right)$ where residuals are computed from a regression including demographic controls and province $\times$ year fixed effect. for different values of $\beta_{2}$.

Table 5: Heterogeneity based on lagged (1982) share of immigrants

\begin{tabular}{lccccc}
\hline & $(1)$ & $(2)$ & $(3)$ & $(4)$ & $(5)$ \\
& All & $<50$ th pctile & $>50$ th pctile & $<33$ rd pctile & $>66$ th pctile \\
& $\mathrm{b} / \mathrm{se}$ & $\mathrm{b} / \mathrm{se}$ & $\mathrm{b} / \mathrm{se}$ & $\mathrm{b} / \mathrm{se}$ & $\mathrm{b} / \mathrm{se}$ \\
\hline$\Delta \overline{I P W}$ & $0.401^{* * *}$ & $0.405^{* * *}$ & $0.347^{* * *}$ & $0.492^{* * *}$ & $0.282^{* *}$ \\
& $(0.082)$ & $(0.094)$ & $(0.102)$ & $(0.105)$ & $(0.122)$ \\
\hline Region-Year FE $^{*}$ & $\sqrt{ }$ & $\sqrt{ }$ & $\sqrt{ }$ & $\sqrt{ }$ & $\sqrt{ }$ \\
Demographic structure $^{a}$ & $\sqrt{ }$ & $\sqrt{ }$ & $\sqrt{ }$ & $\sqrt{ }$ & $\sqrt{ }$ \\
\hline KP stat & 334.8 & 223.9 & 196.7 & 201.8 & 137.7 \\
Cragg-Donald stat & 7876.3 & 3295.7 & 4226.1 & 2339.2 & 2873.5 \\
$N$ & 10140 & 5028 & 5112 & 3279 & 3552 \\
\hline
\end{tabular}

Notes: The sample consists of 3380 cantons, observed over 3 periods: 1995-2002-2007-2012. Robust clustered standard errors are reported between brackets. Corsica is excluded from the sample. $\triangle I P W$ is expressed in thousands of dollar. ${ }^{a}$ : Demographic controls include the age-sex distribution for 7 different categories (0-15 year old, 16-24, ..,74-90, 90 and more), population and population-squared. ${ }^{b}$ : Share of population whose occupation is manual worker ("ouvrier") as 1990. Regressions are weighted by 1990 Census population. ${ }^{*} \mathrm{p}<.10 * * \mathrm{p}<.05,{ }^{* * *} \mathrm{p}<.01$ 
Table 6: Period specific effects

\begin{tabular}{lcccc}
\hline & $(1)$ & $(2)$ & $(3)$ & $(4)$ \\
& OLS & IV & IV & IV \\
& $\mathrm{b} / \mathrm{se}$ & $\mathrm{b} / \mathrm{se}$ & $\mathrm{b} / \mathrm{se}$ & $\mathrm{b} / \mathrm{se}$ \\
\hline$\Delta \overline{I P W} \times \mathrm{I}($ period $=95-02)$ & 0.251 & 0.171 & 0.057 & -0.013 \\
& $(0.248)$ & $(0.393)$ & $(0.389)$ & $(0.392)$ \\
$\Delta \overline{I P W} \times \mathrm{I}($ period $=02-07)$ & $0.37^{* * *}$ & 0.165 & 0.123 & 0.116 \\
& $(0.128)$ & $(0.136)$ & $(0.113)$ & $(0.138)$ \\
$\Delta \overline{I P W} \times \mathrm{I}($ period $=07-12)$ & $0.319^{* * *}$ & $0.655^{* * *}$ & $0.605^{* * *}$ & $0.596^{* * *}$ \\
& $(0.080)$ & $(0.129)$ & $(0.118)$ & $(0.123)$ \\
\hline \hline Region-Year FE & $\sqrt{ }$ & $\sqrt{ }$ & $\sqrt{ }$ & $\sqrt{ }$ \\
Demographic structure ${ }^{a}$ & $\sqrt{ }$ & $\sqrt{ }$ & $\sqrt{ }$ & $\sqrt{ }$ \\
College Share 1990 & & & $\sqrt{ }$ & $\sqrt{ }$ \\
Working Class Share 1990 ${ }^{b}$ & & $60 / 263 / 275$ & $60 / 261 / 273$ & $60 / 254 / 264$ \\
\hline AP stat & & 1415.9 & 1410.5 & \\
Cragg-Donald stat & & 10140 & 10140 & 10140 \\
$N$ & 10140 & & \\
\hline
\end{tabular}

Notes: The sample consists of 3380 cantons, observed over 3 periods: 1995-2002-2007-2012. Robust clustered standard errors are reported between brackets. Corsica is excluded from the sample. $\triangle I P W$ is expressed in thousands of dollar. ${ }^{a}$ : Demographic controls include the age-sex distribution for 7 different categories (0-15 year old, 16-24, ..,74-90, 90 and more), population and population-squared. ${ }^{b}$ : Share of population with a higher education degree and share of population whose occupation is manual worker ("ouvrier") as 1990. Regressions are weighted by 1990 Census population.

\section{A Trade and Employment Data}

We use data on trade from the website un.comtrade.org. The trade data follow the product classification HS 1992 with 6 digit. The data on employment follows the NACE rev 1.1. classification which is equivalent to the 4-digit CPA 2002 classification. To convert HS-1992 6-digit codes into NACE 4-digit codes, we do the following:

1. We use a file available on un.comtrade.org to map HS-1992 into HS-2007.

2. We use one file available on http://ec .europa.eu/eurostat/ramon to map HS-2007 into CPA 2002. The latter maps n-to-one to the NACE rev 1.1.

3. We obtain a correspondence mapping from HS-1992 into NACE rev. 1.1. All HS-1992 6-digit goods that are not uniquely mapped with a NACE 4-digit sector divided across NACE sectors using weights reflecting each sectors initial "importance" in the economy (the weights are the employment share in 1995). Non-uniquely mapped goods account for about $9 \%, 8 \%$ and 6\% of French imports from China for years 1995,2001 and 2007 respectively. 
Table 7: Total French Imports: Uniquely and Non-Uniquely Mapped (\$ millions)

\begin{tabular}{lcccc}
\hline & Total & Uniquely & Non-uniquely & Ratio \\
\hline 1995 & 5,950 & 5,385 & 565 & .095 \\
1996 & 6,833 & 6,236 & 597 & .0873 \\
1997 & 7,495 & 6,874 & 621 & .0828 \\
1998 & 8,178 & 7,505 & 673 & .0823 \\
1999 & 8,943 & 8,237 & 706 & .079 \\
2000 & 10,515 & 9,670 & 845 & .0803 \\
2001 & 10,450 & 9,635 & 815 & .078 \\
2002 & 11,380 & 10,506 & 874 & .0768 \\
2003 & 15,850 & 14,660 & 1,190 & .0751 \\
2004 & 21,398 & 19,871 & 1,527 & .0714 \\
2005 & 26,748 & 24,737 & 2,011 & .0752 \\
2006 & 30,968 & 28,652 & 2,316 & .0748 \\
2007 & 39,533 & 37,015 & 2,518 & .0637 \\
\hline \hline
\end{tabular}

Note: A product code HS-1992 is considered "uniquely mapped" if according it is uniquely mapped according to our mapping HS-1992 $\rightarrow$ HS-1996 $\rightarrow$ NACE built using the conversion tables from RAMON (HS 2007 to CPA) and Comtrade (HS1992 to HS2007). Each observation for product HS1992 that cannot be uniquely mapped to a NACE sector is dropped (either because there is no mapping or the mapping is not unique). Column (4) displays the the trade value non-uniquely matched products as the share of overall imports French imports from China. Trade values are expressed in current dollars.

\section{B Selection of countries}

We primarily use the list by Auer et al. (2013) which includes: China, India, Malaysia, Mexico, Philippines, Thailand, Turkey, Poland, Romania, Slovakia and Bulgaria. 